\title{
Chemical defence of the warningly coloured caterpillars of Methona themisto (Lepidoptera: Nymphalidae: Ithomiinae)
}

\author{
KAMILA F. MASSUDA and JosÉ R. TRIGO* \\ Laboratório de Ecologia Química, Departamento de Zoologia, Instituto de Biologia, Universidade Estadual de Campinas, \\ CP 6109, 13083-970 Campinas, SP, Brazil
}

\begin{abstract}
Key words. Aposematism, Brunfelsia uniflora, Camponotus crassus, Gallus gallus domesticus, learning, Lycosa erythrognatha, predation, Solanaceae, unpalatability
\end{abstract}

\begin{abstract}
The caterpillars of the butterfly Methona themisto (Nymphalidae: Ithomiinae) are conspicuously coloured and feed exclusively on Brunfelsia uniflora (Solanaceae), a plant that is rich in secondary plant substances, which suggests the caterpillars are chemically protected against predators. Results of experiments indicate that predators determine the survival of Methona themisto caterpillars in the field and laboratory bioassays that this organism is eaten by ants and spiders but not chicks. Both the conspicuous orange and black striped colouration and chemical compounds of Methona themisto caterpillars seem to be related to protection against predation by visually hunting predators. Chicks ate proportionally more of the cryptically coloured $1^{\text {st }}$ instar caterpillars than of the conspicuously coloured later instar caterpillars. That Methona themisto caterpillars are chemically defended is supported by the activity of the dichloromethanic extract of $5^{\text {th }}$ instars in preventing predation by chicks. Caterpillars of Methona themisto are aposematic as they are both (1) unpalatable, and (2) their warning signal is easily recognized by potential predators. Chicks learned to avoid the aposematic $3^{\text {rd }}$ or $5^{\text {th }}$ instar caterpillars after one encounter. Mealworms painted to look like caterpillars were also rejected by chicks that had previously encountered Methona caterpillars. Naïve chicks did not avoid eating the painted mealworms, which indicates they do not innately avoid this specific colour pattern.
\end{abstract}

\section{INTRODUCTION}

Lepidoptera caterpillars are subject to high mortality due to predators and parasitoids and have developed many defence mechanisms against their natural enemies (see Bowers, 1993; Heirich, 1993; Montllor \& Bernays, 1993; Stamp \& Wilkens, 1993; Weseloh, 1993), of which distastefulness is one of the best known. Wallace (1987 in Bowers, 1993) proposed such a mechanism to explain why some caterpillars are brightly coloured. The noxious taste or odour of prey, which results in their rejection by predators (Brower, 1984), when associated with a warning colouration, is termed aposematism (Bowers, 1993). The distastefulness of the caterpillars of some butterflies and moths is associated with either stinging or irritant hairs or spines, osmeteria and other eversible glands, regurgitation, toxic leaf material in the gut, sequestration of chemical compounds from host plants, or de novo biosynthesis of defensive compounds (see Brown et al., 1991; Bowers, 1993, and references therein).

The subfamily Ithomiinae are mimetic and aposematic butterflies belonging to the family Nymphalidae and are cited as examples of distasteful models in accounts of both Batesian and Müllerian mimicry (Willmot \& Freitas, 2006 and references therein). There are over 370 species in 45 genera and 10 tribes in this subfamily, and their biology and natural history are well studied. These butterflies are commonly encountered in humid forests from sea level up to $3000 \mathrm{~m}$, from Mexico to southern Brazil, Paraguay and across three Caribbean islands (see Willmott \&
Freitas, 2006 and references therein). The adults are chemically protected against several predators and bioassays indicate that pyrrolizidine alkaloids are responsible for this protection (see Trigo, 2008 for a review).

Nevertheless the defence mechanisms of caterpillars of this subfamily are poorly understood and studied. The sequestration of pyrrolizidine alkaloids by caterpillars of Tithorea harmonia and Aeria olena (Trigo \& Brown, 1990; Trigo et al., 1996) and tropane alkaloids by Placidina euryanassa (Freitas et al., 1996), suggest the caterpillars use these chemicals to protect themselves against predation; other warningly coloured caterpillars, e.g. Melinea, Methona, Athesis, and Patricia are also likely to be chemically defended (Willmot \& Freitas, 2006). A novel mechanism of chemical defence, camouflage based on the chemical similarity of the cuticular lipids of the caterpillars with those of its host plants is described for Mechanitis polymnia (Portugal, 2001; Portugal \& Trigo, 2005). Focusing on chemical defence in Ithomiinae caterpillars it is here proposed to determine whether the warningly coloured caterpillars of Methona themisto also protect themselves against predators using chemicals.

\section{MATERIAL AND METHODS}

\section{Studied organisms}

The butterfly Methona themisto (Hübner, 1818) uses Brunfelsia uniflora (Pohl) D. Don (Solanaceae) as its host plant (Lamas, 1973) and occurs mainly in urban areas (Motta, 1998; Ruszczyk \& Nascimento, 1999). Females generally lay a single egg on the abaxial surface of leaves. Caterpillars are solitary,

\footnotetext{
* Corresponding author; e-mail: trigo@unicamp.br
} 
have a conspicuously black and orange striped colouration in the later intars $\left(3^{\text {rd }}-5^{\text {th }}\right)$ and feed mainly on the abaxial surface of leaves (Fig. 1). Caterpillars take 20 days to complete their development and then, pupate away from the host plant. The life cycle of Methona themisto is described in more detail in Lamas (1973) and Brown \& Freitas (1994). The host plant Brunfelsia uniflora is a Neotropical shrub used as an ornamental (Plowman, 1979) and medicinal plant (Schultes, 1976). This genus of plants is known to contain brunfelsamidine (Lloyd et al., 1985), scopoletine (Mors \& Ribeiro, 1957) and calistegines (Bekkouche et al., 2001).

\section{Caterpillar survival in the field}

In order to verify the role of predators in the survival of Methona themisto caterpillars in nature we compared the survival of caterpillars that were either protected or unprotected against predators on plants in a fragment of forest near Campinas, São Paulo state, Brazil [Mata Ribeirão-Cachoeira (22 $50^{\prime} \mathrm{S}$, $\left.46^{\circ} 55^{\prime} \mathrm{W}\right)$ ] and in an urban environment [Campus of Universidade Estadual de Campinas (UNICAMP) (22 $\left.\left.49^{\prime} \mathrm{S}, 4^{\circ} 05^{\prime} \mathrm{W}\right)\right]$. Eggs were obtained from adults kept in a greenhouse in the Departamento de Zoologia, IB, UNICAMP.

We used 20 potted Brunfelsia uniflora grown in a greenhouse in order to minimize the influence of cues due to herbivory, which might attract natural enemies, and allowed the standardization host plant size ( $1 \mathrm{~m}$ in height). Newly hatched first instar caterpillars ( $\mathrm{n}=20$ individuals/plant) were placed on the abaxial surface of Brunfelsia uniflora leaves (one caterpillar per leaf) and their survival monitored daily until the $5^{\text {th }}$ instar. We randomly choose the leaf which each caterpillar was placed. At each site the plants were either unprotected or protected against predators ( $\mathrm{n}=5$ for each treatment). The plants were protected against predators using the method described by Nogueira-de-Sá \& Trigo (2002). The plants were placed in exclusion cages made of PVC $(1 \times 1 \times 1 \mathrm{~m})$ and covered with a fine mesh, which excluded predators such as birds, wasps and bugs. Tanglefoot ${ }^{\mathrm{TM}}$ resin placed around the base of each plant prevented ants reaching the plants. Pairs of treatments were placed close to each other (1 $\mathrm{m}$ apart) and each pair randomly assigned to positions $10 \mathrm{~m}$ apart. The percentage survival of the last instar $\left(5^{\text {th }}\right)$ was arcsin transformed and compared for the different sites and treatments using repeated measures Anova (Zar, 1999), assuming that as the treatments within each pair were positioned close together they should be similarly attacked by predators.

\section{Bioassays using live caterpillars}

Since ants will attack and kill caterpillars that are not usually ant attended (Smiley, 1985; Montllor \& Beranys, 1993; Freitas \& Oliveira, 1996) and are deterred by distasteful caterpillars (Dyer \& Floyd, 1993; Dyer, 1995a, b; Dyer \& Bowers, 1996; Dyer et al., 2003) ants were used as the predator in laboratory bioassays. The neotropical carpenter ant, Camponotus crassus Mayr (Formicinae), was used as the predator in the bioassays. This species nests in live trees and in dead and decaying logs (Kusnezov, 1951), and is frequently seen patrolling plants in a range of habitats. Ten colonies of Camponotus crassus were collected and maintained in the laboratory following Portugal \& Trigo (2005). The colonies were fed late instar mealworms Tenebrio molitor L. (Coleoptera: Tenebrionidae) $48 \mathrm{~h}$ before the bioassays. In a bioassay one $5^{\text {th }}$ instar Methona themisto caterpillar was offered on a mature leaf of its host plant, Brunfelsia uniflora. The leaves were collected immediately before the bioassays from plants growing in the field at UNICAMP and their petioles temporarily placed in a vial water to prevent the leaves from dessicating. Caterpillar mortality was recorded after $24 \mathrm{~h}$. In addition to $C$. crassus, two other ant species maintained as above, Camponotus rufipes Fabricius (two colonies) and Camponotus rengeri Emery (three colonies), were used as predators in the bioassays.

The wolf spider, Lycosa erythrognatha Lucas (Arachnida: Araneae: Lycosidae), was also used as a predator $(n=30)$. Like ants, they are voracious invertebrate predators but avoid eating chemically protected organisms (Eisner \& Eisner, 1991; Gonzáles et al., 1999; Framenau, 2000; Carrell, 2001). As prior to pupation Methona themisto caterpillars leave their host plant, generally in the $5^{\text {th }}$ instar, they may encounter this predator, as well as ants (see below) in nature. The bioassays using wolf spiders were carried using the method described by Gonzáles et al. (1999). The spiders were collected on the campus of UNICAMP and kept individually in transparent plastic containers $(15 \times 12$ $\mathrm{cm}, \mathrm{d} \times \mathrm{h}$ ) with a ball of water saturated cotton wool and fed weekly with one mealworm. Two weeks prior to their use in the bioassays they received one mealworm. In each bioassay, a single $5^{\text {th }}$ instar caterpillar of Methona themisto, held in a pair of forceps, was offered to the wolf spider by placing it in front of the spider's chelicerae. The response of the spider was recorded as successful if the caterpillar was captured and killed, or not successful, if the caterpillar survived the spider's attack. The spider's response was validated if after the capture of a Methona themisto caterpillar it accepted a mealworm.

Young individuals of Gallus gallus domesticus (L.) (Galliformes: Phasianidae) are often used as models of visually hunting predators (Begossi \& Benson, 1988; Nogueira-de-Sá \& Trigo, 2005). The bioassays were conducted following Nogueira-de-Sá \& Trigo (2005) by first offering a control mealworm. If the mealworm was eaten a caterpillar of Methona themisto was offered and the chick's responses recorded as pecked and eaten, pecked and not eaten, or not pecked (response categories modified from Brower 1958). After offering the caterpillar the chick was offered another mealworm and if the chick ignored or rejected the mealworm the result of that trial was not included in the analysis. Each individual chick was used in only one trial (n $=30$ for each trial). In order to determine whether they could complete their development after their encounter with the predator the pecked and not eaten, and not pecked caterpillars were reared individually. The frequencies of each chick's response were compared using a G-test for contingency tables, followed by a subdivided contingency table as a post hoc test when needed (Zar, 1999, p. 502).

\section{Bioassays with caterpillar and host plant extracts}

To verify if caterpillars of Methona themisto were chemically protected against predators, bioassays using dichloromethanic and aqueous extracts of caterpillars and of its host plant were carried out under laboratory and field conditions. Caterpillars of Methona themisto or fresh leaves of Brunfelsia uniflora were homogenized three times in $\mathrm{MeOH}: \mathrm{H}_{2} \mathrm{O} 4: 1$ (10× volume/weight). The homogenates were filtered, combined and evaporated at low pressure $\left(40^{\circ} \mathrm{C}\right)$ until only the aqueous phase remained. The aqueous phase was extracted three times with dichloromethane, yielding two phases: dichloromethanic and aqueous. The dichloromethanic phase was washed three times with water, which was then discarded. The same procedure was followed with the aqueous phase, which was washed three times with dichloromethane, which was then discarded. This procedure reduces the presence of polar compounds in the dichloromethanic phase, and neutral and apolar compounds in the aqueous phase (J.R. Trigo, pers. obs.). Then the dichloromethanic phase was treated with anhydrous $\mathrm{Na}_{2} \mathrm{SO}_{4}$ and the solvent evaporated as above, yielding a dichloromethanic extract, and the aqueous phase was freeze-dried, yielding the aqueous extract. 


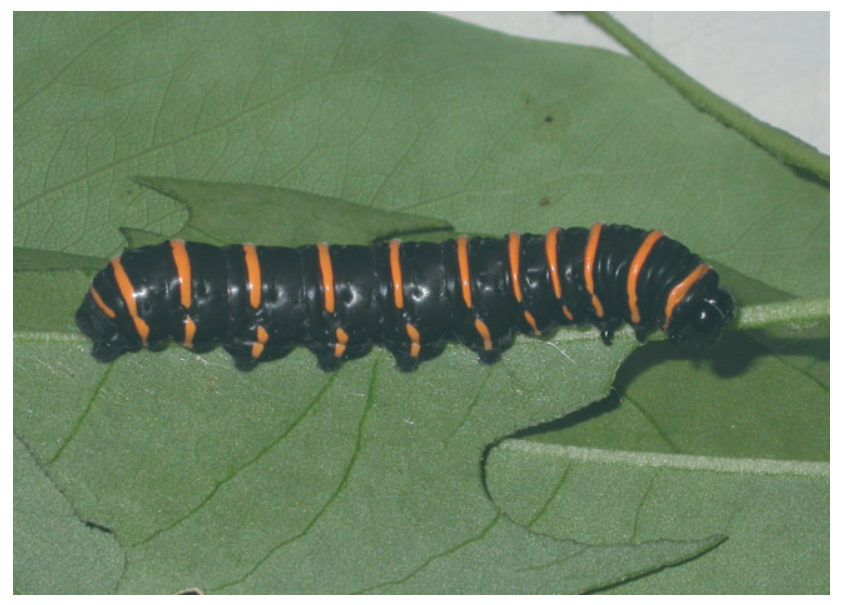

Fig. 1. Fourth instar caterpillar of Methona themisto feeding on Brunfelsia uniflora leaf.

For field bioassays, the procedure described in Nogueirade-Sá \& Trigo (2005) was followed. Extracts of Methona themisto were topically applied to freeze dried mealworms at a concentrations of 1 or 5 caterpillar equivalents (see Portugal \& Trigo, 2005 for calculations) in $20 \mathrm{ml}$ dichloromethane or water; extracts of Brunfelsia uniflora were also applied at concentrations of $0.1,1$ or $10 \%$ of the mealworm's dry weight, since nothing is known about the fate of the secondary plant compounds of Brunfelsia uniflora in Methona themisto. Five caterpillar equivalents were used to compensate for the loss of the extract applied to mealworms as some of it could penetrate into the body of the caterpillars instead of remaining on the cuticle (Portugal \& Trigo, 2005). The bioassays with caterpillar and plant extracts were carried out independently. Potted host plants $(n=10)$, growing in greenhouse as above, were transferred to the field sites and placed along a trail at $10 \mathrm{~m}$ intervals. Immediately after the application of the extracts or solvents, mealworms were glued using Super Bonder ${ }^{\mathrm{TM}}$ to the abaxial surface of a different randomly chosen leaf on the same plant. Host plants received one mealworm from each treatment (see above). The disappearance of mealworms was recorded over a period of 3 days.

For the bioassays with Gallus gallus domesticus (a predator that rejected caterpillars of Methona themisto - see Results) we used mealworms treated with either host plant or caterpillar extracts, following the same procedure as in the bioassays with live caterpillars. The number of chicks used for the bioassay of each extract ranged from 13 to 30 . The percentages of mealworms that were pecked and eaten in the different treatments were compared using the modified Chi-square test for comparison among more than two proportions with a post hoc Tukey-type multiple comparison test (Zar, 1999, p. 562).

\section{Conspicuousness versus distastefulness: learning by Gallus} gallus domesticus chicks

To assess whether chicks avoid caterpillars of Methona themisto after their first encounter with them, which would indicate learning, 19 and 16 naïve (without previous visual experience of this caterpillar) chicks were submitted to three bioassays (as described above) on consecutive days, using either $3^{\text {rd }}$ or $5^{\text {th }}$ instar Methona themisto caterpillars. The chicks' responses were recorded as above.

To evaluate the possibility that the orange/black stripes of Methona themisto caterpillars discourage attack by visually hunting predators the response of 20 naïve and 19 experienced chicks (with previous experience of encountering this caterpillar

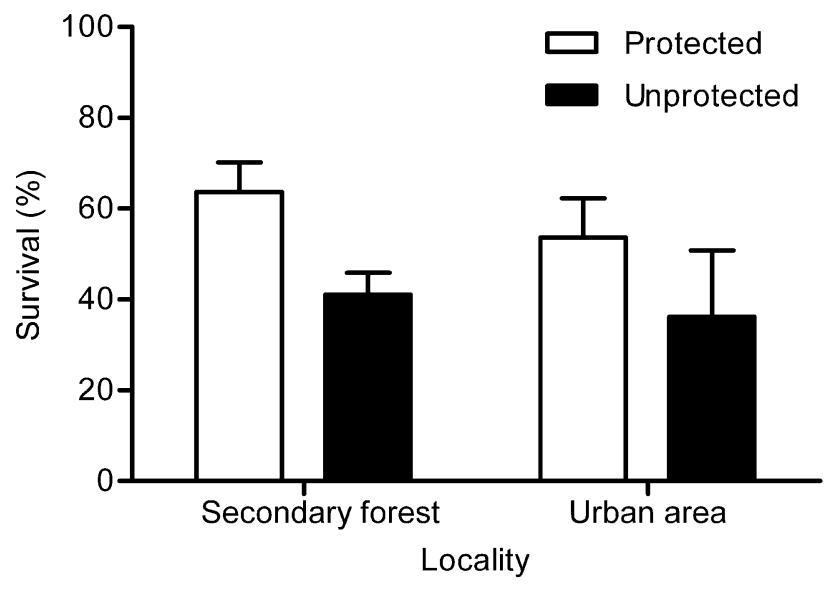

Fig. 2. Percentage survival (mean $\pm \mathrm{se}$ ) of Methona themisto caterpillars on protected and unprotected plants at two sites. See Results for statistics.

in other bioassays) were recorded. In this bioassay freeze dried mealworms painted with different colour patterns, using non toxic ink (Acrilex $\left.{ }^{\mathrm{TM}}\right)$, were sequentially offered as follow: (1) control mealworm, (2) mealworm painted with orange/black stripes, (3) mealworm painted brown (this colour is very similar to the natural colour of mealworms so if the ink has an adverse effect on the chicks' responses, it would be detected here), and (4) a control mealworm. A record was made of the responses of each chick to the differently treated mealworms. The frequencies of each chick's responses were compared using a G-test for contingency tables (Zar, 1999).

\section{RESULTS}

\section{Survival of caterpillars in the field}

In the field, the percentage survival of $5^{\text {th }}$ instar caterpillars was significantly higher on protected plants than unprotected plants independent of the study area (secondary forest or urban area) (repeated measures Anova, $F_{1,8}$ $=11.213, \mathrm{P}=0.01$, Fig. 2). Although this result indicates that caterpillars are eaten by predators in the field no act of predation was observed during this study. Predation of pupae by wasps (Agelaia vicina Hymenoptera: Vespidae) and myrmicine ants was observed.

\section{Bioassays using live caterpillars}

In the bioassays using Camponotus crassus ants all the $5^{\text {th }}$ instar caterpillars were eaten. The ants from the two nests of Camponotus rufipes and three of Camponotus rengeri also showed the same response. In all these bioassays the caterpillars reacted aggressively to the ants by regurgitating, but this was insufficient to deter the predators. The spider Lycosa erythrognatha also attacked and consumed all the caterpillars offered. As in both of these bioassays, all the $5^{\text {th }}$ instar caterpillars were eaten the response of ants and spiders to $3^{\text {rd }}$ and $1^{\text {st }}$ instar caterpillars was not determined.

Bioassays using Gallus gallus domesticus indicated that its response depended on the age of the prey ( $\mathrm{G}$ test $3 \times 3$, $\chi^{2}=28.56$, df $=4, \mathrm{P}<0.0001$, Fig. 3). When the responses pecked and rejected, and not pecked were combined, and compared with pecked and eaten, the age dependency was confirmed ( $\mathrm{G}$ test $2 \times 3, \chi^{2}=26.38$, df $=$ 


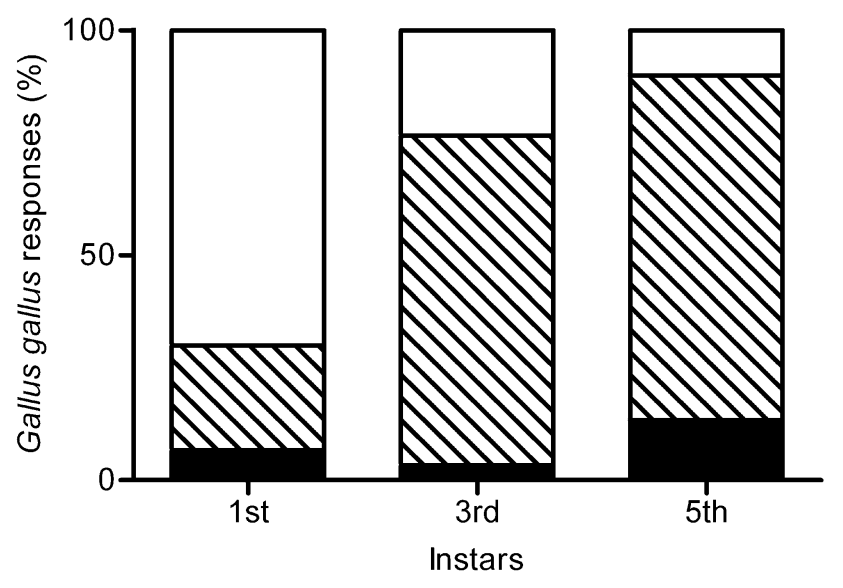

Fig. 3. Responses of chicks offered $1^{\text {st }}, 3^{\text {rd }}$ or $5^{\text {th }}$ instar Methona themisto caterpillars. White $=$ pecked and eaten, diagonal stripes $=$ pecked and not eaten, black $=$ not pecked. See Results for statistics.

$2, \mathrm{P}<0.0001) ; 3^{\text {rd }}$ and $5^{\text {th }}$ instar caterpillars suffered significantly less predation than $1^{\text {st }}$ instar caterpillars ( $\mathrm{G}$ test $\left.2 \times 2, \chi_{\text {corr.Yates }}^{2}=22.88, \mathrm{df}=1, \mathrm{P}<0.0001\right)$. Chicks reacted aversively to $3^{\text {rd }}$ or $5^{\text {th }}$ instar caterpillars with head shaking behaviour, even when they did not peck them; the same behaviour was observed in the biossays below. First instar caterpillars did not survive being attacked, but 80 and $100 \%$ of $3^{\text {rd }}$ and $5^{\text {th }}$ instar, respectively, survived and reached the adult stage.

\section{Bioassays using caterpillar and host plant extracts}

At both field sites (forest fragment and urban environment) neither the aqueous or dichloromethanic extracts of the host plant or of Methona themisto caterpillars provided protection against predation. All mealworms treated with these extracts and the controls were eaten. Myrmicine ants were observed eating the mealworms.

Both extracts of the host plant did not deter predation by Gallus gallus domesticus. Nevertheless, the dichloromethanic extract of Methona themisto deterred chicks and its effect was concentration dependent $\left(\chi^{2}=64.5, \mathrm{df}=4\right.$, $\mathrm{P}<0.0001$, Fig. 4).

\section{Conspicuousness versus distastefulness: learning by Gallus gallus domesticus chicks}

These bioassays used only $3^{\text {rd }}$ and $5^{\text {th }}$ instar Methona themisto, which are unpalatable to Gallus gallus domesticus and are conspicuously coloured (orange and black stripes). The response of Gallus gallus domesticus to both instars depended on the chicks previous experience; if the had experienced a previous distasteful encounter with a caterpillar they did not attack ( $\mathrm{G}$ test $2 \times 3, \chi^{2}=11.76$, df $=2, \mathrm{P}=0.0028$ and $\chi^{2}=8.81, \mathrm{df}=2, \mathrm{P}=0.0122$, for $3^{\text {rd }}$ and $5^{\text {th }}$ instar respectively; only data for the $5^{\text {th }}$ instar are presented in Fig. 5).

Naïve Gallus gallus domesticus were not deterred and ate the mealworms that were painted with conspicuous colours. Only $10 \%$ of the chicks that had previously encountered $3^{\text {rd }}$ instar Methona themisto fed on mealworms painted with stripes like those on the body of

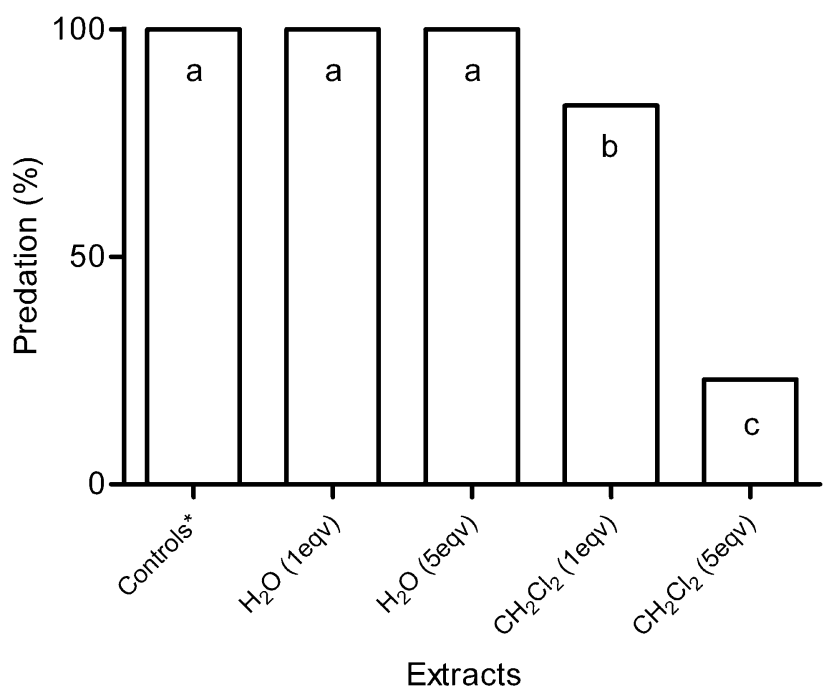

Fig. 4. Percentage of chicks that ate mealworms topically treated with the different extracts of Methona themisto caterpillars at different caterpillar equivalents. $\mathrm{H}_{2} \mathrm{O}=$ aqueous extracts, $\mathrm{CH}_{2} \mathrm{Cl}_{2}=$ dicloromethanic extracts. Different letters in the columns indicate significant differences at $5 \%$ (Comparison of proportions, $\chi^{2}=64.5$, df $\left.=4, \mathrm{P}<0.0001\right)$. ${ }^{*}$ Both aqueous and dichlorometanic controls.

Methona themisto; all experienced chicks ate control mealworms (without paint) and mealworms that were painted brown ( $\mathrm{G}$ test $2 \times 4, \chi^{2}=68.00$, df $=3, \mathrm{P}<$ 0.0001, Fig. 6).

\section{DISCUSSION}

The conspicuous colouration of caterpillars of Methona themisto suggests they are chemically protected against predators, as has been reported for other similarly coloured animals (see Ruxton et al., 2004 for a review). Nevertheless, the results of the exclusion cage experiment suggest that predation can reduce the survival of Methona themisto caterpillars in nature, although predation of this developmental stage was not observed during this study. The laboratory bioassays also indicate that this organism is not protected against ants and spiders. Portugal (2001) has already shown that Methona themisto caterpillars are preyed upon by Camponotus crassus in the laboratory.

That the conspicuous orange and black striped colouration of Methona themisto caterpillars and their distastefulness protects them against predation by visually oriented predators is revealed by the results of the bioassays in which chicks were used as the predator. Chicks ate the $1^{\text {st }}$ instar caterpillars, which are not conspicuously coloured and may only contain low concentrations of deterrent chemicals, but pecked and rejected $3^{\text {rd }}$ and $5^{\text {th }}$ instar caterpillars. The $3^{\text {rd }}$ and $5^{\text {th }}$ instar caterpillars are conspicuously coloured and may contain high concentrations of deterrent chemicals, sufficient to elicit an adverse response from the chicks. The presence of repellents cannot be discarded since chicks showed aversive responses to caterpillars without pecking them. Warning odours such pyrazines were found in several aposematic insects (Moore et al., 1990). That Methona themisto caterpillars 


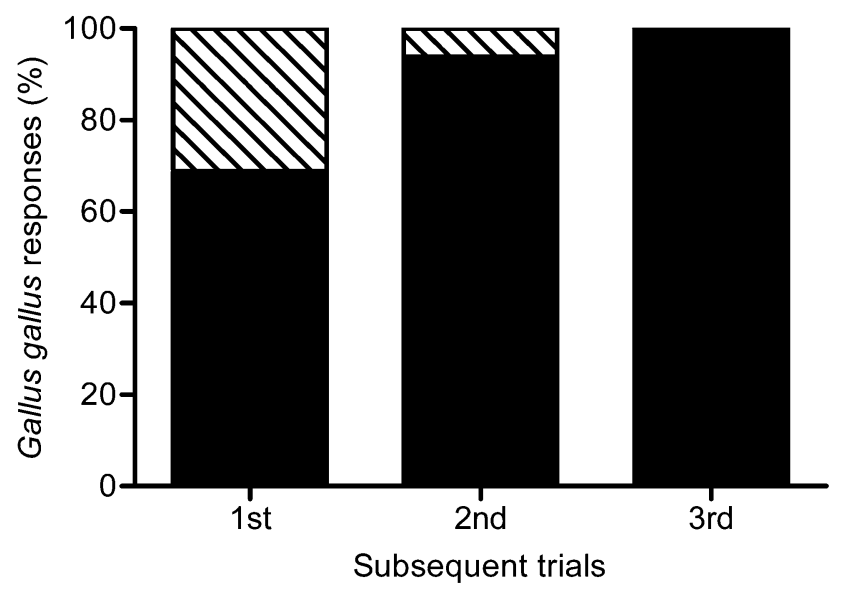

Fig. 5. Responses of chicks to $5^{\text {th }}$ instar Methona themisto caterpillars offered on three consecutive days to the same individuals. Diagonal stripes $=$ pecked and not eaten, black $=$ not pecked. G test $2 \times 3, \chi^{2}=8.81, \mathrm{df}=2, \mathrm{P}=0.0122$.

are chemically defended is supported by the observation that chicks avoid eating mealworms treated with the dichloromethanic extract of $5^{\text {th }}$ instar caterpillars. Thus, the evidence presented here indicates that caterpillars of Methona themisto qualify are aposematic as they are both unpalatable and there warning colouration makes them easily recognized by potential predators.

Chicks learned to avoid aposematic $3^{\text {rd }}$ or $5^{\text {th }}$ instar caterpillars after just one encounter, and most of the caterpillars survived the attack. Mealworms with a similar colouration to $3^{\text {rd }}$ instar caterpillars were also rejected by chicks that had previously encountered $3^{\text {rd }}$ instar Methona themisto. It is well documented that warning colouration can accelerate learning to avoid distasteful prey by predators hunting by sight and thereby increase the survival of the prey (see Ruxton et al., 2004, p. 94). Also, aposematic insects have a high chance of surviving attacks by predators. Järvi et al. (1981) show that the great tit Parus major on first encountering swallowtail caterpillars, Papilio machaon, attack them but learn to avoid them after experiencing their distastefulness; all the caterpillars survive the attack. Wiklund \& Järvi (1982) in experiments with birds also demonstrate that naïve predators often release distasteful prey insects unharmed after tasting them. Wiklund, Järvi and collaborators conclude that the evolution of aposematism can be explained on the basis of individual selection alone. Our results for Methona themisto caterpillars support this suggestion as distastefulness directly benefits the caterpillars (see Guilford 1990 for a discussion of the evolution of aposematism by kin- or individual selection).

Naïve chicks did not respond to the colour of the mealworms, that is they do not show an innate avoidance of specific colour patterns. It is suggested that predators that lack an innate avoidance of warningly coloured prey might be expected to quickly learn to avoid prey that is harmful (Ruxton et al., 2004), like the chicks in the present study.

That the adults and caterpillars of some Lepidoptera are chemically defended is well known and attributable to

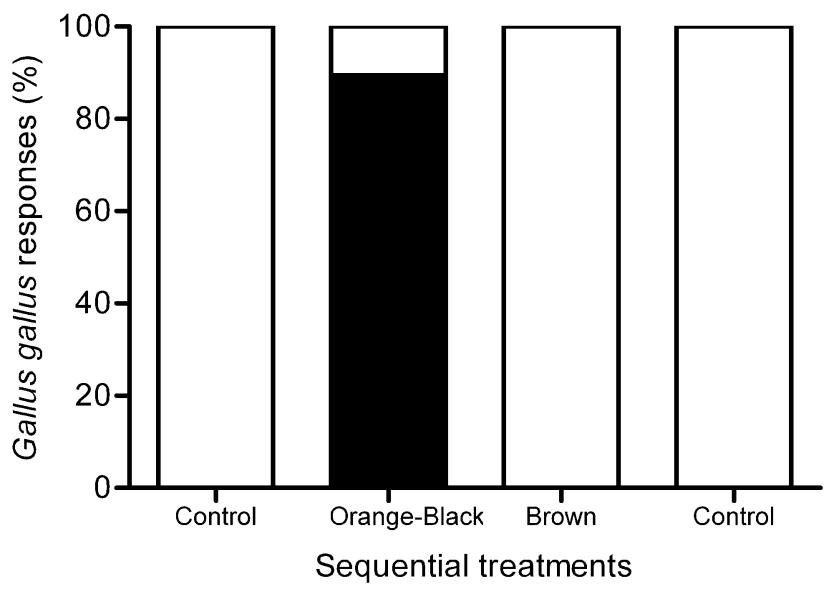

Fig. 6. Response of chicks that had previous experience of $3^{\text {rd }}$ instar Methona themisto caterpillars to control, orange-black painted, brown painted and control mealworms presented sequentially. White $=$ pecked and eaten, black $=$ not pecked. $\mathrm{G}$ test $2 \times 4, \chi^{2}=68.00, \mathrm{df}=3, \mathrm{P}<0.0001$.

different classes of substances active against either birds, reptiles, spiders or ants (see Trigo, 2000; Nishida, 2002 for reviews). However this protection is not absolute. It is interesting to note that pyrrolizidine alkaloids, widespread mainly in adults of Ithomiinae and Danainae butterflies and caterpillars and adults of Arctiidae moths (see Trigo, 2008 for a review) are sometimes reported to be ineffective against birds (Ritland, 1991; Yosef et al., 1996). Caterpillars of Utetheisa ornatrix contain pyrrolizidine alkaloids but are eaten by ants (Ferro et al., 2006; Guimarães et al., 2006). Tropane alkaloids are effective against monkeys but not spiders (Freitas et al., 1996). Hartmann et al. (2003) verified that the harvestman Mitopus morio (Phalangidae), a generalist predator, which eats the larvae of the pyrrolizidine alkaloidcontaining Oreina cacaliae (Coleoptera: Chrysomelidae), is able to detoxify these compounds. Why are some compounds active against some predators and inactive against others, as reported here for Methona themisto caterpillars? Their activity must be correlated with a set of factors that are poorly studied, such as the taxon of the predator, the predator's capacity to detoxify foreign compounds, the evolution of gustatory receptors of foreign compounds in predators and the evolutionary history of predator and prey.

Chemical defence of the caterpillars of ithomiine butterflies has been poorly studied. Among the basal tribes of Ithomiinae, to which Methona belongs, it is suggested that the chemical protection of immature stage is widespread (Willmott \& Freitas, 2006), since caterpillars of Aeria and Tithorea sequester pyrrolizidine alkaloids from their apocynaceous hostplants (Trigo \& Brown, 1990; Trigo et al., 1996) and are conspicuously coloured (Brown \& Freitas, 1994). The more derived species, Mechanitis polymnia (Willmot \& Freitas, 2006), whose caterpillars feed on Solanum species (Solanaceae), has a novel defence. The caterpillars are chemically camouflaged from predatory ants by vitue of the close similarity of caterpillar and plant cuticular lipids (Portugal, 2001; 
Portugal \& Trigo, 2005); they are also rejected by chicks (J.R. Trigo, pers. observ.). Another derived species, Placidina euryanassa, whose caterpillars feed on Brugmansia suaveolens (Freitas, 1993; Freitas et al., 1996) are eaten by ants (Portugal, 2001) and wasps but rejected by chicks (Arab \& Trigo, in prep.). Warningly coloured caterpillars, such as those of most Melinaeini (like Melinaea), the closely related Athesis + Patricia and several Napeogenini, Dircennini and Godyridini, are also possibly chemically defended against predators (Willmot $\&$ Freitas, 2006; Trigo, 2008). The results presented here support the hypothesis that conspicuously coloured Methona themisto caterpillars are chemically protected against predation and that these chemicals are more effective against predators that hunt visually, that is, the caterpillars are aposematic. Caterpillars of Methona themisto are parasitized by Zigofrontina sp. (Diptera: Tachinidae), and several other parasitoids that emerge from the pupae (Nardi et al., 2006), however, it is unknown if the same chemicals that protect the caterpillars from attack by visually hunting predators are effective against parasitoids. Furthermore, whether the compounds involved in chemical protection against predation and are sequestered from the host plant or biosynthesized de novo remains to be investigated.

ACKNOWLEDGEMENTS. We thank F. Nogueira-de-Sá, P.C. Motta, K. Lucas da Silva-Brandão, A.V. Lucci Freitas, M. Alves Stanton, A. Arab and two anonymous reviewers for commenting on the manuscript. J. Carlos da Silva, P.C. Balduíno, R. Terto and E. Garcia kindly helped with the field work. A.V. Lucci Freitas kindly supplied the photograph of the Methona themisto caterpillar. We thank also the Condomínio Colinas do Atibaia for the permission to work in the area. This research is part of an MSc dissertation by KFM funded by a research grant from the Katherine McLennan Brown Foundation, UNICAMP. This work was also supported by grants from CNPq and FAPESP awarded to JRT (304969/2006-0 and 98/01065-7).

\section{REFERENCES}

Begossi A. \& Benson W.W. 1988: Host plants and defense mechanisms in Oedionychina (Alticinae). In Jolivet P., Petitpierre E. \& Hsiao T.H. (eds): Biology of Chrysomelidae (Coleoptera). Kluwer Academic Publishers, Dordrecht, pp. 57-71.

Bekkouche K., Daali Y., Cherkaoui S., Veuthey J.L. \& Christen P. 2001: Calystegine distribution in some solanaceous species. Phytochemistry 58: 455-462.

Bowers M.D. 1993: Aposematic caterpillars: life-styles of the warningly colored and unpalatable. In Stamp N.E. \& Casey T.M. (eds): Caterpillars. Ecological and Evolutionary Constraints on Foraging. Chapman \& Hall, New York, pp. 331-371.

BROWER J.Z. 1958: Experimental studies of mimicry in some north american butterflies: Part I. The monarch, Danaus plexippus, and viceroy, Limenitis archippus archippus. Evolution 12: 32-47.

Brower L.P. 1984: Chemical defense in butterflies. In VaneWright R.I. \& Ackery P.R. (eds): The Biology of Butterflies. Academic Press, New York, pp. 109-134.

Brown K.S. \& Freitas A.V.L. 1994: Juvenile stages of Ithomiinae: overview and systematics (Lepidoptera: Nymphalidae). Trop. Lepid. 5: 9-20.
Brown K.S., Trigo J.R., Francini R.B., Morais A.B.B. \& МоттA P.C. 1991: Aposematic insects on toxic host plants: coevolution, colonization, and chemical emancipation. In Price P.W., Lewinsohn T.M., Fernandes G.W. \& Benson W.W. (eds): Plant-Animal Interactions. Evolutionary Ecology in Tropical and Temperate Regions. John Wiley, New York, pp. 375-402.

CARRELl J.E. 2001: Response of predaceous arthropods to chemically defended larvae of the pyralid moth Uresiphita reversalis (Guenee) (Lepidoptera: Pyralidae). J. Kans. Entomol. Soc. 74: 128-135.

DYER L.A. 1995a: Tasty generalists and nasty specialists? A comparative study of antipredator mechanisms in tropical lepidopteran larvae. Ecology 76: 1483-1496.

DYER L.A. 1995b: Effectiveness of caterpillar defenses against three species of invertebrate predators. J. Res. Lep. 34: 48-68.

DYer L.A. \& Bowers M.D. 1996: The importance of sequestered iridoid glycosides as a defense against an ant predator. J. Chem. Ecol. 22: 1527-1539.

DYer L.A. \& FLOYD T. 1993: Determinants of predation on phytophagous insects. The importance of diet breadth. Oecologia 96: $575-582$.

Dyer L.A., Dodson C.D. \& Gentry G. 2003: A bioassay for insect deterrent compounds found in plant and animal tissues. Phytochem. Anal. 14: 381-388.

EISNER T. \& EISNER M. 1991: Unpalatability of the pyrrolizidine alkaloid containing moth, Utetheisa ornatrix, and its larva, to wolf spiders. Psyche 98: 111-118.

Ferro V.G., Guimarães P.R. \& Trigo J.R. 2006: Why do larvae of Utetheisa ornatrix penetrate and feed in pods of Crotalaria species? Larval performance vs. chemical and physical constraints. Entomol. Exp. Appl. 121: 23-29.

Framenau V.W., Finley L.A., Allan K., Love M., Shirley D. \& Elgar M.A. 2000: Multiple feeding in wolf spiders: the effect of starvation on handling time, ingestion rate, and intercatch intervals in Lycosa lapidosa (Araneae: Lycosidae). Austr. J. Zool. 48: 59-65.

Freitas A.V.L. \& OliveiRa P.S. 1996: Ants as selective agents on herbivore biology: effects on the behaviour of a nonmyrmecophilous butterfly. J. Anim. Ecol. 65: 205-210.

Freitas A.V.L. 1993: Biology and population dinamics of Placidula euryanassa, a relict ithomiine butterfly (Lepidoptera: Nymphalidae). J. Lepid. Soc. 47: 87-105.

Freitas A.V.L., Trigo J.R., Brown K.S., Witte L., Hartamann T. \& BaratA L.E.S. 1996: Tropane and pyrrolizidine alkaloids in the ithomiines Placidula euryanassa and Miraleria cymothoe (Lepidoptera: Nymphalidae). Chemoecology 7: 61-67.

Gonzales A., Rossini C., Eisner M. \& Eisner T. 1999: Sexually transmitted chemical defense in a moth (Utheteisa ornatrix). Proc. Natl. Acad. Sci. USA 96: 5570-5574.

GuILFORD T. 1990: The evolution of aposematism. In Schmidt J.O. \& Evans D.L. (eds): Insect Defenses: Adaptative Mechanisms and Strategies of Prey and Predators. State University of New York Press, New York, pp. 23-61.

Guimarães P.R., Raimundo R.L.G., Bottcher C., Silva R.R. \& TRIGo J.R. 2006: Extrafloral nectaries as a deterrent mechanism against seed predators in the chemically protected weed Crotalaria pallida (Leguminosae). Austral Ecol. 31: 776-782.

Hartmann T., Häggström H., Theuring C., Lindigkeit R. \& RAHIER M. 2003: Detoxification of pyrrolizidine alkaloids by the harvestman Mitopus morio (Phalangidae) a predator of alkaloid defended leaf beetles. Chemoecology 13: 123-127.

HeINRICH B. 1993: How avian predators constrain caterpillar foraging. In Stamp N.E. \& Casey T.M. (eds): Caterpillars. Eco- 
logical and Evolutionary Constraints on Foraging. Chapman \& Hall, New York, pp. 224-247.

Järvi T., Sillén-Tullberg B. \& Wiklund C. 1981: The cost of being aposematic. An experimental study of predation on larvae of Papilio machaon by the great tit Parus major. Oikos 36: $267-272$.

Kusnezov N. 1951: El género Camponotus en la Argentina. Acta Zool. Lilloana 11: 183-255.

Lamas G. 1973: Taxonomia e evolução dos gêneros Ituna Doubleday (Danainae) e. Paititia gen. n., Thyridia Hübner e Methona Doubleday (Ithomiinae) (Lepidoptera, Nymphalidae). PhD Thesis, Universidade de São Paulo, São Paulo, Brazil.

Lloyd H.A., Fales H.M., Goldman M.E., Jerina D.M., Plowman T. \& Schultes R.E. 1985: Brunfelsamidine - a novel convulsant from de medicinal Brunfelsia grandiflora. Tetrahedron Lett. 26: 2623-2624.

Montllor C.B. \& Bernays E.A. 1993: Invertebrate preators and caterpillar foraging. In Stamp N.E. \& Casey T.M. (eds): Caterpillars. Ecological and Evolutionary Constraints on Foraging. Chapman \& Hall, New York, pp. 170-202.

Moore B.P., Brown W.V. \& Rothschild M. 1990: Methylalkylpyrazines in aposematic insects, their hostplants and mimics. Chemoecology 1: 43-51.

Mors W.B. \& RiBEIRO O. 1957: Occurrence of scopoletin in the genus Brunfelsia. J. Org. Chem. 22: 978-979.

Мотта P.C. 1998: Estudos macro e microevolutivos nas borboletas Ithomiinae (Nymphalidae). PhD Thesis, Universidade Estadual de Campinas, Campinas, Brazil.

Nardi C., Guerra T.M., Orth A.I. \& Tavares M.T. 2006: Himenópteros parasitóides associados a pupas de Methona themisto (Lepidoptera, Nymphalidae) em Florianópolis, Santa Catarina, Brasil. Iheringia 96: 373-375.

NishidA R. 2002: Sequestration of defensive substances from plants by Lepidoptera. Annu. Rev. Entomol. 47: 57-92.

Nogueira-DE-SÁ F. \& Trigo J.R. 2002: Do fecal shields provide physical protection to larvae of the tortoise beetles Plagiometriona flavescens and Stolas chalybea against natural enemies? Entomol. Exp. Appl. 104: 203-206.

NogueIrA-DE-SÁ F. \& TRIGo J.R. 2005: Faecal shield of the tortoise beetle Plagiometriona aff. flavescens (Chrysomelidae: Cassidinae) as chemically mediated defence against predators. J. Trop. Ecol. 21: 189-194.

Plowman T. 1979: The genus Brunfelsia: a conspectus of the taxonomy and biogeography. In Hawkes J.G., Lester R.N. \& Skelding A.D. (eds): The Biology and Taxonomy of the Solanaceae. 1st ed. Academic Press, London, pp. 475-491.

Portugal A.H.A. 2001: Defesa química em larvas da borboleta Mechanitis polymnia (Nymphalidae: Ithomiinae). MSc Thesis. Universidade Estadual de Campinas. Campinas, Brazil.

Portugal A.H.A. \& Trigo J.R. 2005: Similarity of cuticular lipids between a caterpillar and its host plant: A way to make prey undetectable for predatory ants? J. Chem. Ecol. 31: 2551-2561.

RitLAND D.B. 1991: Palatability of aposematic queen butterflies (Danaus gilippus) feeding on Sarcostemma clausum (Asclepiadaceae) in Florida. J. Chem. Ecol. 17: 1593-1610.
RuszczyK A. \& Nascimento E.S. 1999: Biologia dos adultos de Methona themisto (Hübner, 1818) (Lepidoptera, Nymphalidae, Ithomiinae) em praças públicas de Uberlândia, Minas Gerais, Brasil. Rev. Bras. Biol. 59: 577-583.

Ruxton G.C., Sherratt T. \& Speed M.P. 2004: Avoiding Attack. The Evolutionary Ecology of Crypsis, Warning Signals and Mimicry. Oxford University Press, Oxford, 249 pp.

SchULtes R.E. 1976: Solanaceous hallucinogens and their role in the development of New World cultures. In Hawkes J.G., Lester R.N. \& Skelding A.D. (eds): The Biology and Taxonomy of the Solanaceae. 1st ed. Academic Press, London, pp. 137-160.

SMiLey J.T. 1985: Heliconius caterpillars mortality during establishment on plants with and without attending ants. Ecology 67: $516-521$.

Stamp N.E. \& Wilkens R. 1993: On the cryptic side of life: being unapparent to enemies and the consequences for foraging and growth of caterpillars. In Stamp N.E. \& Casey T.M. (eds): Caterpillars. Ecological and Evolutionary Constraints on Foraging. Chapman \& Hall, New York, pp. 283-330.

TRIGO J.R. 2000: The chemistry of antipredator defense by secondary compounds in neotropical Lepidoptera: Facts, perspectives and caveats. J. Braz. Chem. Soc. 11: 551-561.

TRIGO J.R. 2008: Chemical ecology of ithomiine butterflies. In Epifano F. (ed.): Current Trends in Phytochemistry. Research Signpost, Kerala, India, pp. 141-165.

TRIGO J.R. \& BROwN K.S. 1990: Variation of pyrrolizidine alkaloids in Ithomiinae: a comparative study between species feeding on Apocynaceae and Solanaceae. Chemoecology 1: $22-29$.

Trigo J.R., Brown K.S., Witte L., Hartamnn T., Ernst L. \& Barata L.E.S. 1996: Pyrrolizidine alkaloids: Different acquisition and use patterns in Apocynaceae and Solanaceae feeding ithomiine butterflies (Lepidoptera: Nymphalidae). Biol. J. Linn. Soc. 58: 99-123.

WeSELOH R.M. 1993: Potential effects of parasitoids on the evolution of caterpillar foraging behavior. In Stamp N.E. \& Casey T.M. (eds): Caterpillars. Ecological and Evolutionary Constraints on Foraging. Chapman \& Hall, New York, pp. 203-223.

WIKLUND C. \& JäRVI T. 1982: Survival of distasteful insects after being attacked by naive birds - a reparisal of the theory of aposematic coloration evolving through individual selection. Evolution 36: 998-1022.

Willmott K.R. \& Freitas A.V.L. 2006: Higher-level phylogeny of the Ithomiinae (Lepidoptera: Nymphalidae): classification, patterns of larval hostplant colonization and diversification. Cladistics 22: 297-368.

Yosef R., CArrel J.E. \& Eisner T. 1996: Contrasting reactions of loggerhead shrikes to two types of chemically defended insect prey. J. Chem. Ecol. 22: 173-181.

ZAR J.H. 1999: Biostatistical Analysis. 4th ed. Prentice-Hall, New Jersey, 663 pp.

Received July 4, 2008; revised and accepted January 7, 2009 